Progressive Physics Journal
Volume 1, Nomor 1, Mei 2020
ISSN $2722-7707$ (online)
http://jurnal.fmipa.unmul.ac.id/index.php/ppj/index

\title{
Studi Penggunaan Bolus Berbahan Silicone Rubber terhadap Dosis Permukaan pada Radioterapi Berkas Elektron
}

\author{
Gede Wiratma Jaya ${ }^{1,2}$, Heri Sutanto ${ }^{1,2^{*}}$, Eko Hidayanto ${ }^{1,2}$, Galih Puspa Saraswati ${ }^{3}$ \\ ${ }^{1}$ Departemen Fisika, Universitas Diponegoro, Semarang, Indonesia \\ ${ }^{2}$ Smart Material Research Center (SMARC), Universitas Diponegoro, Semarang, Indonesia \\ ${ }^{3}$ Instalasi Radioterapi, Rumah Sakit Ken Saras, Semarang, Indonesia \\ *E-mail korespondensi: herisutanto@fisika.undip.ac.id
}

\begin{abstract}
Radiotherapy is a method of externally cancer therapy using a Linear Accelerator (LINAC) tool. LINAC can produce photon and electron beam energy which will be used to treat cancer according to the position of the cancer in the patient's body. When using an electron beam to treat cancer on the surface of the skin, it is found that there is a lack of a radiation dose. The use of bolus with Silicone Rubber (SR) material is a solution to provide an increase in radiation doses in the surface area of the skin. In this study SR boluses were made using the sol-gel method with dimensions of $17 \mathrm{~cm} \times 17 \mathrm{~cm} \times 1 \mathrm{~cm}$. The SR Bolus was illuminated with an applicator field area of $10 \mathrm{~cm} \times 10 \mathrm{~cm}$ and energy variations of $5 \mathrm{MeV}$ and $7 \mathrm{MeV}$. The surface dose produced at the moment without using a bolus for $5 \mathrm{MeV}$ and $7 \mathrm{MeV}$ energy is $1.60 \mathrm{~Gy}$ and $1.61 \mathrm{~Gy}$. When using bolus, the surface dose of $5 \mathrm{MeV}$ and $7 \mathrm{MeV}$ energy is $2.12 \mathrm{~Gy}$ and $2.06 \mathrm{~Gy}$. From the results of this study it can be concluded that the use of SR bolus can increase a higher surface dose without using bolus.
\end{abstract}

Key Words: Radiotherapy, Bolus, Silicone Rubber, Electron Beam, Surface Dose

\section{PENDAHULUAN}

Radioterapi merupakan metode alternatif dalam melakukan pengobatan kanker, pengobatan kanker menggunakan radioterapi eksternal dengan alat linear accelerator (LINAC) [1]. LINAC dapat menghasilkan berkas radioterapi elektron dan foton yang bergantung pada posisi dan letak kanker dari permukaan kulit [2]. Pada kasus tertentu seperti pengobatan kanker pada permukaan kulit dosis radiasi yang diterima dari berkas elektron belum mampu memberikan dosis permukaan secara maksimal dikarenakan adanya efek skin sparing [2]. Untuk itu diperlukan material yang dapat memberikan peningkatan dosis radiasi permukaan, material tersebut dikenal sebagai bolus.

Bolus merupakan sarana radioterapi dengan memiliki karakteristik material yang mirip dengan jaringan dan ditempatkan pada permukaan kulit pada saat radioterapi menggunakan berkas elektron maupun foton [3]. Selain memberikan peningkatan dosis permukaan, bolus memiliki fungsi untuk menghentikan laju penetrasi elektron agar fokus pada jaringan kanker di 
permukaan kulit dan membantu dalam memberikan distribusi dosis permukaan yang seragam $[4,5]$. Bolus yang digunakan harus memiliki beberapa karakteristik, yaitu memiliki tingkat elastisitas yang baik, tidak terdapat gelembung udara pada permukaan bolus, tidak bersifat beracun dan tidak mengalami perubahaan bentuk pada saat dilakukan penyinaran radiasi $[6,7]$.

Material Bolus yang digunakan pada penelitian ini adalah Silicone Rubber (SR), SR memiliki beberapa karakteristik, yaitu memiliki ketahanan dengan berbagai jenis radiasi [8], tidak beracun [9] dan memiliki harga yang murah dibandingkan dengan material bolus lainnya. Material SR telah digunakan untuk membuat organ tiruan untuk aplikasi brachytherapy, hal ini dikarenakan SR memiliki sifat mekanik yang sama dengan otot manusia [10]. Berdasarkan karakteristik yang dimiliki SR maka penelitian ini memiliki tujuan untuk mengetahui seberapa besar nilai dosis radiasi permukaan yang dihasilkan dengan berkas radiasi elektron.

\section{METODE PENELITIAN}

\subsection{Sintesis Bolus SR}

Bahan yang digunakan untuk membuat bolus adalah silicone rubber (SR) RTV-52 dan bluesil catalyst $60 \mathrm{R}$ sebagai katalis untuk mempercepat proses pengerasan material SR. Bolus yang dibuat memiliki dimensi $17 \mathrm{~cm} \times 17 \mathrm{~cm} \times 1 \mathrm{~cm}$. Proses sintesis menggunakan metode solgel dengan perbandingan SR dan katalis sebesar 25:1. Proses pencampuran menggunakan mixer dilakukan kurang lebih selama 6 menit. Hasil pencampuran dituangkan pada cetakan kayu dengan alas papan plastik yang sudah diolesi silicone oil. Sampel didiamkan kurang lebih selama 24 jam dan jika sudah kering sampel diangkat dari cetakkan dan siap untuk dilakukan pengujian.

\subsection{Pengujian Dosis Permukaan}

Pengujian dosis permukaan dilakukan menggunakan berkas radiasi elektron yang dihasilkan dari alat Linear Accelerator (LINAC). Energi radiasi yang digunakan sebesar $5 \mathrm{MeV}$ dan $7 \mathrm{MeV}$ dengan lapangan aplikator sebesar $10 \mathrm{~cm} \times 10 \mathrm{~cm}$. Solid water phantom disiapkan pada meja pasien LINAC dan mengatur jarak antara sumber radiasi dengan permukaan solid water phantom (source to surface dose (SSD)) sebesar $100 \mathrm{~cm}$. Untuk mengukur dosis permukaan, detektor plan parallel chamber yang sudah terhubung dengan electrometer diletakkan pada permukaan LINAC dengan kondisi tanpa menggunakan bolus. Kemudian dilakukan penyinaran radiasi menggunakan energi $5 \mathrm{MeV}$ dan $7 \mathrm{MeV}$ secara bergantian. Lalu bolus diletakkan diatas detektor dan dilakukan penyinaran kembali dengan energi radiasi yang sama. Adapun prosedur pengambilan data dapat dilihat pada Gambar. 1. Dosis radiasi yang ditampilkan pada electrometer dalam satuan nanocoulomb $(\mathrm{nC})$, untuk mengubah dalam satuan Gray (Gy) menggunakan persamaan yang dikembangkan oleh International Atomic Energy Agency (IAEA) pada buku panduan IAEA TRS 398 [11]. 


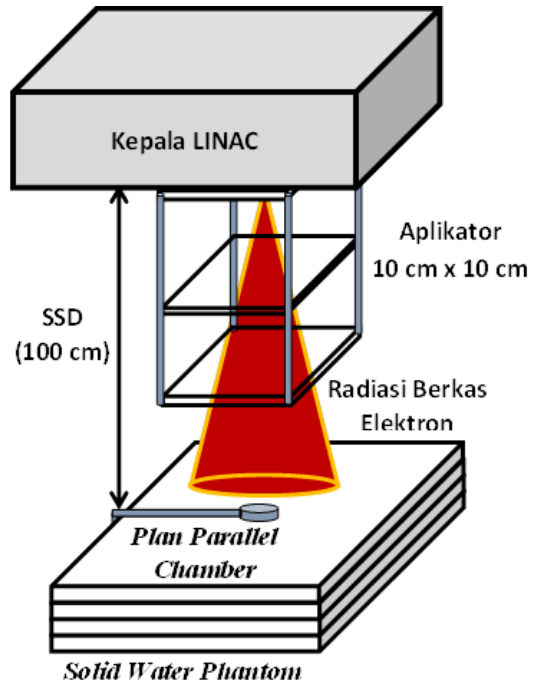

(a)

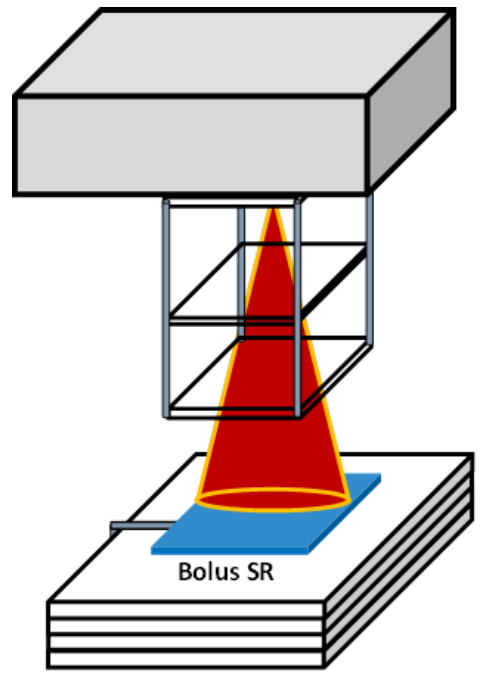

(b)

Gambar 1. Skema pengambilan data dosis permukaan pada solid water phantom (a) tanpa menggunakan bolus, (b) menggunakan bolus.

\section{HASIL DAN PEMBAHASAN}

Hasil

Berdasarkan dari hasil pengambilan data diperoleh nilai permukaan dosis permukaan menggunakan berkas elektron pada energi $5 \mathrm{MeV}$ dan $7 \mathrm{MeV}$ yang dapat dilihat pada Gambar 2 . Dari hasil tersebut menunjukkan bahwa terjadi peningkatan dosis radiasi pada saat menggunakan bolus untuk setiap energi. Namun dosis radiasi pada $7 \mathrm{MeV}$ jauh lebih rendah dibandingkan dengan dosis radiasi pada energi $5 \mathrm{MeV}$ pada saat menggunakan bolus.

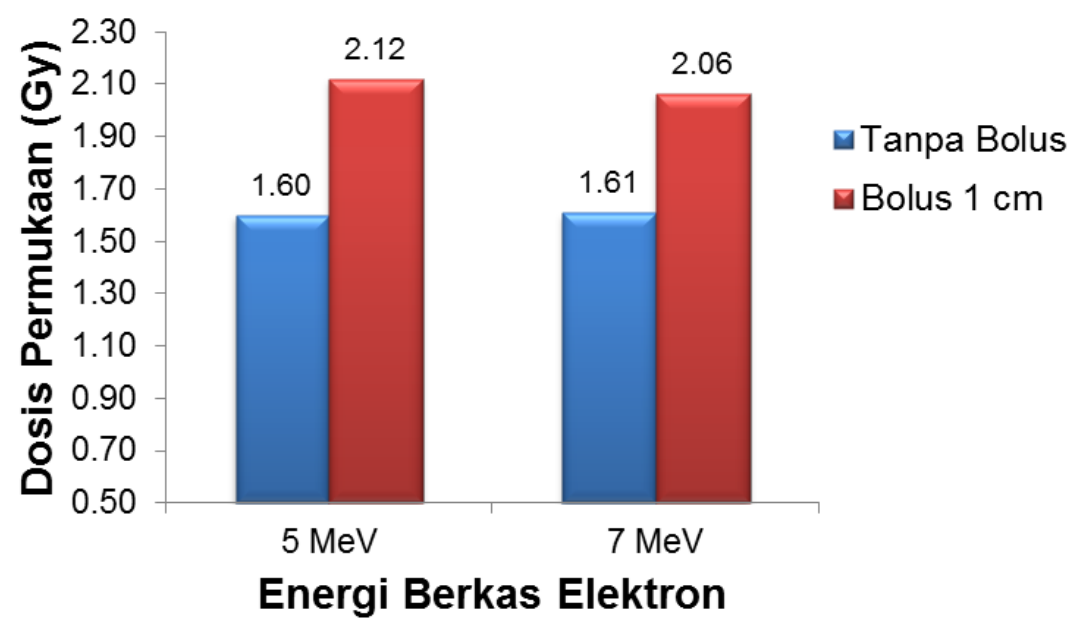

Gambar 2. Dosis permukaan dengan energi berkas elektron sebesar $5 \mathrm{MeV}$ dan $7 \mathrm{MeV}$. 


\section{Pembahasan}

Berdasarkan dosis permukaan yang diperoleh, secara keseluruhan penggunaan bolus SR dapat meningkatkan dosis permukaan dengan selisih yang cukup besar. Akan tetapi jika dilihat data peningkatan dosis permukaan pada saat menggunakan bolus terjadi penurunan dosis permukaan. Secara teori semakin besar energi yang digunakan maka dosis radiasi yang dihasilkan akan lebih meningkat [2]. Namun pada hasil penelitian ini menunjukkan hasil yang berbeda. Salah satu kemungkinan yang menyebabkan terjadinya penurunan dosis permukaan adalah pengaruh energi kinetik yang dimiliki oleh partikel elektron. Pada saat elektron dengan energi tinggi, maka kecepatan partikel elektron tersebut akan meningkat dan ketika elektron mengenai bolus, elektron masih memiliki energi yang cukup untuk melewati permukaan solid water phantom sampai akhirnya akan kehabisan energi pada kedalaman tertentu dari solid water phantom tersebut. Sehingga dosis permukaan yang dihasilkan jauh lebih rendah dibandingkan dengan energi yang rendah.

\section{KESIMPULAN}

Penggunaan bolus berbahan silicone rubber (SR) dapat memberikan peningkatan dosis permukaan yang cukup tinggi. Adanya penurunan dosis permukaan pada saat menggunakan bolus untuk energi berkas elektron yang tinggi disebabkan adanya peningkatan kecepatan partikel elektron yang mengakibatkan partikel elektron mampu menembus lebih dalam lapisan solid water phantom.

\section{UCAPAN TERIMA KASIH}

Penulis mengucapkan terima kasih kepada Laboratorium Fisika Material, Departemen Fisika Universitas Diponegoro sebagai tempat kegiatan sintesis bolus SR dan Rumah Sakit Ken Saras yang telah memberikan bantuan dalam melakukan pengambilan data.

\section{DAFTAR PUSTAKA}

[1] Azizah, M., Milvita, D., Herlida, S., dan Sandy, K.Y.P. 2016. Verifiksi Dosis Radiasi Kanker Menggunakan TLD-100 pada Pasien Kanker Payudara dengan Penyinaran Open System. Jurnal Fisika Unand 5, pp. 147-152.

[2] Podgorsak, E.B. 2005. Radiation Oncology Physics: A Handbook for Teacher and Students. Vienna: Internastional Atomic Energy Agency.

[3] Rancangkapti, N., Hariyanto, A.P., Mariyam, F.U., Almira, L., Endarko, dan Haris, B. 2019. Dosimetry analysis of homemade bolus using propylene glycol for photon MegaVoltage and Eelectron radiation therapy. Journal of Physics: Conf. Series 1248, pp. $1-6$.

[4] Demir, B., Okutan, M., Cakir, A., Goksel, E., and Bilge, H. 2008. The Effect of Oblique Electrom Beams to the Surface Dose Under the Bolus. Medical Dosimetry 34, pp. 311316. 
[5] Günhan, B., Kemikler, G., and Koca, A. 2003. Determination of Surface Dose and The Effect of Bolus To Surface Dose In Electron Beams. Medical Dosimetry 28, pp. 193-198.

[6] Lothfy, F.A., Mustafa, I.S., Yahya, Z.S., Ishak, S.A., and Daud, N. M. 2015. To Study The Durian Seed As A New Substrate For Bolus In Radiotherapy. Proceedings of Sixteenth The IIER International Conference, Kuala Lumpur, Malaysia, pp. 110-113.

[7] Adamson, J.D., Cooney, T., Demehri, F., Stalnecker, A., Geogras, D., Yin, F., and Krikpatrick, J. 2017. Charecterization of Water-Clear Polymeric Gels for Use as Radiotherapy Bolus. Technology in Cancer Treatment, pp. 1-6.

[8] Shaojin, H., Jianbin, H., Zhang, C., Wang, J., Chen, L. Xingming, B., Lin, J. Xiaoze, D. 2018. Performance improvement in nano-alumina filled silicone rubber composites by using vinyl tri-methoxysilane. Polymer Testing 67, pp. 295-301.

[9] Xu, Y., Gao ,Q., Liang, H., and Zheng, K. 2018. Effects of functional graphene oxide on the properties of phenyl silicone rubber composites. Polymer Testing 67, pp. 295-301.

[10] Li, P., Jiang, S., Yu, Y., Yang, J., and Yang, Z. 2015. Biomaterail characteristics and applicatoion of silicone rubber and PVA hydrogels mimicked in organ groups for prostate brachytherapy. Journal of The Mechanical Behavior of Biomedical Material 49, pp. 220234.

[11] International Atomic Energy Agency (IAEA). 2000. Absorbed Dose Determination in External Beam Radiotherapy; An International Code of Practice for Dosimetry Based on Standards of Absorbed Dose to Water", Technical Report Series No.398, IAEA: Vienna. 